been without fever. I sent her to the hospital and next day there was consultation of a good many eminent otologists, and they all decided to operate, except one man who said he thought the patient should be treated by conservative methods. I insisted on operation. The patient had had a frontal headache since and before the operation and during the course of this after treatment there had been exacerbations of temperature, pulse, etc. I took the responsibility of this case and operated, cleaned up everything very thoroughly, and everything went all right for twenty-four hours, when the patient had a chill, the temperature went to 105 and continued for thirty-six hours between 105 and 103 , then descended, followed by another chill and elevation of temperature, and quite profuse perspiration. The blood count was something like thirteen or fourteen to eighteen thousand. I took the blood count three or four times a day, the polymorphonuclears being something like 69 per cent. I was very much worried. as you can imagine, having insisted on the operation, and I went so far as to cancel my reservation to attend this meeting, when to my great joy on dressing the case one morning a little red spot appeared anterior to the ear; it was a case of erysipelas. You cannot differentiate these cases and the only thing to do is to wait. I do not believe that valuable time is lost in obscure cases. I believe it is a distinct advantage to wait, and in 100 cases they will come out better than if you immediately jump in and open every case of sinus that has symptoms of sepsis.

Dr. Harry L. Pollock, Chicago: Dr. Graham did not touch on a very important thing regarding the diagnosis in double otitis media. I remember one case in a child with double otitis media, both about the same time and with the same discharge, in which there was an unquestionable sinus infection. There was a question of which side was causing the trouble. An otologist diagnosed thrombosis, and said he would have to open up one side and possibly the other; but the people objected and the case came to us in the hospital. On examination, we noticed on the left side less discharge than on the right, so we told the people that the sinus thrombosis was on the left side. We operated and found it on that side and the patient made an uneventful recovery. This was some years ago, before the West-Beck symptom had been brought to our attention. This consists of compressing the opposite jugular and getting a dilation of the veins of the forehead and fundus oculi. In four cases $I$ found it was positive and operation proved the contention. I tried it in quite a number of cases of mastoid in which I suspected thrombosis. Some cases were negative and it was positive at other times, but I did not operate without the other classical symptoms. In the four the test was alssolutely positive.

Dr. H. B. Graham, San Francisco: I have not touched on the treatment of these sinus thrombosis cases; the paper is limited entirely to the diagnosis. The treatment is very important, but ought to be written up in another paper. Treatment is entirely dependent on the diagnosis. I am sorry that anybody would ever give the impression that opening a vein in a septic field is of little importance. It is a very serious proposition and I should like it to go on record here that opening a vein in a septic field is taking your patient's life in your hands. It is a dangerous proposition. It is far better not to open that vein and take the chances of a future operation than to open that vein and not have a chance for a future operation. Patients have died from the accidental opening of a vein while doing a mastoid operation.

The question of double otitis is an interesting subject and one that has caused a great deal of trouble. There is a case on record of Oppenheim in which he operated on one sicle; there had been an examination made of the other ear and the drum was found intact but slightly reddened. His attention was called to the fact that there was trouble on that side. He opened up the right side, expecting to do a sinus exenteration, but found the sinus free and sent the patient to lied. The patient died. At necropsy a sinus thrombosis was found on the other side, which could have been attended w) if the left side had been opened.

\section{CASEIN-MILK FEEDING IN INFANCY AND} CHILDHOOD *

\section{WALTER GELLHORN, M.D.} SEATTLE

The foremost aim of modern pediatrics is to spread the knowledge that there is no better food for infants than mother's milk, and as a result the rather neglected research of the digestive disorders of nursing infants is beginning to occupy a larger space in the medical literature. The better acquainted the profession is with these disorders, the smaller will be the number of children who are weaned unnecessarily and exposed prematurely to the dangers of artificial feeding. But the unavoidable fact that there always will be a very large number of infants for whom only artificial food is available has stimulated the endeavor to find the standard food which, like breastmilk, will require quantitative rather than qualitative alterations. The encouraging results obtained with such modifications as advised by Friedenthal and by Schloss $^{1}$ give reasonable hope that the near future will bring us a milk organically and inorganically so closely approximating mother's milk that it might be called a fair substitute. But it already has been pointed out that, aside from hypothetic biologic differences, chemical limitations alone will never permit the creation of an absolute substitute. Furthermore, it would be necessary to imitate colostrum also, the great importance of which, for the first days of life, is recognized. ${ }^{2}$

The therapeutic value of these adaptations to human milk is not yet sufficiently investigated, and for the present the interest of the profession is centered on recent methods of curing certain nutritional disorders without attempting to simulate breast-milk in their preparations. Of course no modification, not even human milk, will be successful unless used correctly and with proper confidence, conditions which make a knowledge of the infantile organism in health and disease an essential requirement. A physician with such equipment will be able to overcome a great number of nutritional disorders with comparatively simple methods, especially if utilizing the knowledge that a single constituent of the milk is not harmful in itself, but only if fed in incorrect relation to the others, both the organic and inorganic ones. Such individualization requires exceptional skill, and those recent modifications already contain the different constituents in a correlation which makes the milk of great therapeutic value in most of the nutritional disturbances of a fermentative origin.

The first and most important representative of this class is the albumin-milk advised by Finkelstein and Meyer, ${ }^{3}$ the therapeutic success of which is based on its antifermentative action. This effect is obtained through the reduction simultaneously of whey and lactose and through an increase of casein and calcium. The value of albumin-milk is praised by every one who has had an opportunity to use the correct preparation, and all agree that they obtained results where formerly breast-milk alone could have saved the child. The greatest handicaps for the use of this valuable modi-

* Read before the Section on Diseases of Children at the SixtySixth. Annual Session of the American Medical Association, San rancisco, June, 1915

1. Schloss: Säuglingsernährung, 1912, S. Karger.

2. Langstein: Lehmann's Jahres Kurse, 1912, 1913. 
fication are the taste and the difficult preparation (the powdered product is unreliable), facts which led to recommendations of simpler substitutes. ${ }^{4}$ Engel $^{5}$ succeeded, through skilful handling of rennet, to obtain a finely divided coagulum of casein and fat from which is poured off part of the whey. He avoids by his method the difficult breaking up of the cheese and the addition of buttermilk, which cannot be obtained everywhere in perfect form. The disadvantage of his modification, with which he obtained excellent therapeutic success, lies in the not fully eliminated, uncertain action of rennet and the great care necessary in warming the milk to feeding temperature. Stoeltzner ${ }^{0}$ and Feer, ${ }^{7}$ in their modifications, dispense with the use of rennet entirely. They reduce whey and lactose by diluting their milks, and add prepared casein and calcium to obtain the antifermentative action and the much desired formation of fat-soap stools in diarrheic conditions.

Stoeltzner adds $20 \mathrm{gm}$. of a casein-calcium preparation, larosan, to a formula consisting of 500 c.c. of milk and 500 c.c. of water, and adds to the latter, after a few days, from 1 to 5 per cent. of dextrimaltose, according to the case. His milk conforms pretty closely to albumin-milk with the exception of the lower percentage of fat.

Feer uses sodium caseinate, and increases the calcium by giving up to $3 \mathrm{gm}$. of calcium lactate daily if casein. Both authors recommend their modifications as permanent food for healthy infants.

My own observations conformed pretty closely to the experience of these authors, but after a short trial I found that with my material I could improve results by making not only the carbohydrates but also the fat a variable constituent. Recently Miller ${ }^{9}$ and Hoobler ${ }^{10}$ have published similar views. Hoobler reports a satisfactory substitute for albumin-milk in using 16 ounces of fat-free buttermilk, 16 ounces of water and $10 \mathrm{gm}$, of powdered casein. His mixture contains 2.8 per cent. protein, 0.25 per cent. fat and 2 per cent. carbohydrates, to which cream can be adder, if advisable. The drawback to this formula lies in the difficulty of obtaining the proper buttermilk. The powdered casein he recommends has been used in my County Hospital practice for economical reasons, and was found just as valuable as Feer's and Stoeltzner's preparations. Its strong odor is restricting its usefulness considerably in private practice, in which I now am employing the sodium caseinate almost exclusively. It is equal in value to larosan and much cheaper. ${ }^{11}$

We have known for years that casein fed in daily quantities from 15 to $20 \mathrm{gm}$. is harmless for the youngest nursing infants, and recent investigations by Holt and Levene $e^{12}$ and by Bosworth and Bowditch ${ }^{13}$ have proved the same for bottle babies even in much

COMPOSITION OF CASEIN MILK AND OTHER MILKS

\begin{tabular}{|c|c|c|c|c|c|c|c|c|c|}
\hline & Proteins & liat & Lactose & Ash & Chlorin & $\mathrm{P}_{2} \mathrm{O}_{5}$ & $\mathrm{CaO}$ & $\mathrm{K}_{2} \mathrm{O}$ & $\mathrm{Na}_{2} \mathrm{O}$ \\
\hline 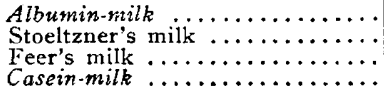 & $\begin{array}{l}30 \\
35 \\
26 \\
30\end{array}$ & $\begin{array}{l}25 \\
17.5 \\
23 \\
11.5\end{array}$ & $\begin{array}{l}15 \\
23 \\
20 \\
23\end{array}$ & $\begin{array}{l}4.9 \\
\dddot{4} .4 \\
4.6\end{array}$ & $\begin{array}{l}0.4 \\
0.20 \\
0.5\end{array}$ & $\begin{array}{l}1.28 \\
1.22 \\
1.35 \\
1.4\end{array}$ & $\begin{array}{l}0.93 \\
1.36 \\
1.05 \\
0.6\end{array}$ & $\begin{array}{l}0.87 \\
0.87 \\
0.8\end{array}$ & $\begin{array}{l}0.69 \\
\dddot{0} . \dot{59} \\
0.8\end{array}$ \\
\hline
\end{tabular}

necessary. He emphasizes especially the high fat content of his mixture, obtained through the addition of 20 per cent. cream. His formula ${ }^{8}$ consists of : 500 c.c. of whole milk, 50 c.c. of cream, from 10 to $50 \mathrm{gm}$. of dextrimaltose, $15 \mathrm{gm}$. of sodium caseinate, and 600 c.c. of water. This means that he added to his milk 10 per cent. of cream, from 1 to 10 per cent. of dextrimaltose, 3 per cent. of sodium caseinate and about as much water as milk and cream together. The calorific value of 1,000 c.c. of this milk amounts to 600 calories. The treatment will have to begin with varying quantities, according to the case, as advised by Finkelstein for his albumin-milk but the increase in carbohydrates can be postponed a little longer, because both modifications, Stoeltzner's and Feer's, contain more sugar from the beginning. In favorable cases the full amount of food should be reached inside of one week or ten days, that is, according to Feer, 100 c.c. of milk per 2 pounds of body weight. The difficult task is the dêtermination of the time for increasing the carbohydrates. Stoeltzner reports for his larosan-milk the same good results as with albumin-milk, and is supported herein by a number of writers. Feer states that in some of the severest cases his casein-cream-milk has proved inferior to albunin-milk, which seems to be of higher therapeutic value on account of the freshly coagulated

4. The limitation of this praper forbids the discussion of all the dif ferent substitites recommended.

5. Engel: Deutsch. med. Wchnschr., 1913.

6. Stoeltzner: München. med. Wchinschr., 1913

7. Feer, E.: Jahrb. f. Kinderh., July, 1913

8. Both modifications have to be boiled. larger quantities. Thomas and Hornemann demonstrated that high casein feedings increase the resistance of suckling pigs against tuberculosis, and Langstein reports clinical observations which show that such feedings increase the immunity of infants against infections in general. My own experience with high protein feedings, which I have used empirically for years, has never demonstrated the development of lowered resistance in my patients, and I was very glad to learn through Feer and Stoeltzner of methods employing increased quantities of casein systematically.

The following modification, made from 4 per cent. milk and used almost exclusively for the cases reported, does not represent more than an adaptation of their teachings to my material:

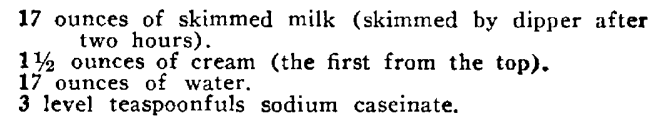

The mixture is boiled, if used therapeutically, and pasteurized if for rather prolonged feeding periods. It represents a skimmed milk to which 10 per cent. of

9. Miller: Arch. Pediat., 1914.

10. Hoobler: Arch. Pediat., 1914

11. It seems that practically any powdered casein will be serviceable, provided it is not too old and is clean. No preparation of this kind should ever be dispensed in a glass bottle.

12. Holt, L. E., and Levene, P. A.: The Infiuence of High Protein Feeding on the General Metabolism, on the Intestinal Flora and on 1912 , p. 265 . 1912, p. 265 13. Bosworth, A. W., and Bowditch, H. I.: Casein in Infant Feeding,
Am. Jour. Dis. Child., August, 1914, p. 120. 
cream and 2 per cent. of casein have been added. ${ }^{14}$ The calorific value, after addition of 5 per cent. dextrimaltose, amounts to about 440 calories per thousand c.c., and the tabulated comparison shows that it contains only half as much fat as albumin-milk, two thirds of its calcium and 0.8 per cent. more of lactose.

In case the relation between calcium and fat should be unsatisfactory in an individual case, additions of calcium lactate will prove of assistance; as much as $5 \mathrm{gm}$. per day have been given. ${ }^{15}$ The additional sugar used was dextrimaltose (from 1 to 7 per cent.) in private practice and granulated table sugar in the County Hospital, the latter without apparent bad results. In practically all the cases barley or oatmeal water ( 1.5 per cent.) was used in place of water.

Following Feer's advice, the attempt was made, and usually with success, to reach the full amount inside of ten days, that is, 100 c.c. of skimmed milk with 10 c.c. of cream and 2 per cent. of sodium caseinate per about 2 pounds of body weight. ${ }^{16}$ In the majority of cases, the increase of fat to 2 and 2.5 per cent. of the total mixture was started at first after that time, but some children required a higher percentage of fat sooner. ${ }^{17}$ In severe cases an addition of sugar was not. started before the third or fourth day. According to the case, a water period from six to twenty-four hours accompanied by an enema and castor oil preceded the administration of the milk.

In successful cases the diarrheic stools became formed inside of a few days, frequently even after twenty-four hours. The alkaline movements resembled buttermilk stools. The appearance of very hard stools was an indication for an increase in fat and sugar.

It was characteristic in favorable cases that the formerly very restless children became quiet and appeared happy even at a time when the food supply was quite insufficient. The initial loss in weight was comparatively small in the majority of children. Among the great number of children, kept on this food for considerable time, only one case of infantile scurvy developed. The child was raised on this modification until 8 months old, when it began to refuse anything but the milk for several weeks, and was easily cured by forced feedings of vegetables and fruit juices.

During the last year no child was kept on the preparation much longer than the symptoms required, because it was found that in a number of cases the weight increased more rapidly on the ordinary modifications, for which the tolerance had increased considerably during treatment. A few days after the mixture had been fed in a quantity adequate to the child's weight, the casein was dropped abruptly.

This report is based on the obsetvations of 163 children of which reliable data could be obtained. The investigations were started twenty-two months ago. Nineteen of the children were younger than 1 month, seventy-three were from 1 to 6 months old. Only thirty of these children were treated in hospitals. According to clinical classification there were:

14. With the milk at my disposal an addition of 2 per cent. casein proved sufficient. One teaspoonful of sodium caseinate equals $3.5 \mathrm{gm}$. 15. Aschenheim gives from 7 to $10 \mathrm{gm}$. without causing any harm. 16. Feer found that 100 c.c. of whole milk, etc., per 2 pounds of weight will cover the child's need. In using skimmed milk this quantity weight will cover the child's need. In using skimmed milk
will be insufficient in most cases until more cream is added.

17. Milk (4 per cent.) allowed to stand two hours after delivery: upper $11 / 2$ ounces of cream $=16$ per cent. fat; $2 \frac{1 / 2}{2}$ ounces $=12$ per cent.; 3 ounces $=15.8$ per cent. fat.
1. Children with normal stools, twelve. The majority of these children had to be weaned abruptly. There were two failures; both children became more or less colicky and did not gain satisfactorily.

2. Premature children, two. Both babies were two montlis premature. One was started on the fourth day of life and did well in spite of a severe ophthalmoblennorrhea. The other baby received at first mixed feeding for about two weeks.

3. Mixed feeding, eighteen, with good results, especially marked in infants formerly suffering from dyspepsia on breast-milk alone. In most of these babies, ordinary cow's milk modifications had caused dyspeptic symptoms.

4. Atrophic babies, twelve children, very much under weight and producing more or less dyspeptic stools. One failure, no death.

5. Infants suffering from acute and subacute intestinal indigestion, seventy-two. Under this heading are included difficult feeding cases and the milder and severest forms of the acute stages. There were five failures, no death.

6. Alimentary intoxication, one. The child could not be saved.

7. Dysentery, three, with one death. The child came under treatment on the seventh day of the disease. In the other two patients there was no outspoken superiority of the food to be noticed.

8. Eczema, twelve. In all cases the movements improved rapidly, but in two of them no influence on the skin condition was noticeable.

9. Carbohydrate dyspepsia in older children, twenty. Here the food proved exceedingly valuable to take the place of plain milk, which could not be digested.

10. Parenteric infection, four.

11. Typhoid fever, one.

12. Postoperative feeding, two. In all these cases, meteorism was favorably influenced.

13. Tetany with rachitis, four. In all these children the preparation had been started on the third or fourth day without recurrence of symptoms.

\section{CONCLUSIONS}

1. Casein-milk feedings have been found to be successful as temporary food in allaitement-mixte and whenever it was necessary to wean a very young child abruptly. Although they do not seem to produce any harm during prolonged use, the advantages they offer are not sufficiently clear to recommend their substitution for the ordinary milk modifications in normal children.

2. They cannot replace breast-milk in some of the severest cases, but in the great majority of nutritional disturbances, as seen in private practice, they will be found to be of assistance. They are indicated in disorders of a fermentative origin, and can be fed here in rapidly increasing doses regardless of the stool picture, provided the child does not develop symptoms of alimentary intoxication. Through their use may be avoided the prolonged or repeated therapeutic hunger periods with their deteriorating influence on the child's organism, which are so frequently the cause of turning an originally mild into a serious disorder. ${ }^{18}$

Cobb Building.

18. In addition to the references already given, the following may be consulted:

Leopold, J. S.: Experiences with Whey Modified Milk in Infant Feeding, Am. Jour. Dis. Child., September, 1914, p. 196.

Wegener: München. med. Wchnschr., 1914.

Forcart: München. med. Wchnschr., 1913.

Forcart: München. med. Wchnschr.,
Ostrowski: Arch. f. Kinderh., 1914.

Rost: Arch. Pediat., 1914.

Rost: Arch. Pediat, 1914.
Stolte: Jahrb. t. Kinderh., lxxiv.

Stolte: Jahrb. t. Kinderh., lxxiv.
Aschenheim: Monatschr. f. Kinderh., 1913, xii.

Leichtentritt: Arch. f. Kinderh., 1914. 